\title{
Innate and discretionary accruals quality and corporate governance: A case study of Tehran Stock Exchange
}

\author{
Hossein Panahian, Hassan Ghodrati and Majid Nazari*
}

Department of Accounting, Islamic Azad University, Kashan Branch, Kashan, Iran

\begin{tabular}{l}
\hline A R T I C L E I N F O \\
\hline Article history: \\
Received June 28, 2012 \\
Received in Revised form \\
August, 26, 2012 \\
Accepted 29 August 2012 \\
Available online \\
6 September 2012 \\
\hline Keywords: \\
Innate and discretionary \\
accruals quality \\
Corporate governance \\
Tehran Stock Exchange \\
Transparency
\end{tabular}

\begin{abstract}
A B S T R A C T
In this paper, we present an empirical study to find the relationship between discretionary accruals quality as well as innate accruals quality and portion of non-executive board of directors, concentration of ownership ratio and board size in Tehran Stock Exchange. The survey selects 118 qualified stocks from this exchange and using a random technique chooses 42 firms. The study implements two linear regression techniques to estimate the first part of the information and then using structural equation modeling examines six hypotheses. Based on the results of this survey we can conclude that an increase on non-executive members positively influences on discretionary accruals quality and negatively influences innate accruals quality. Concentration of ownership ratio positively influences on discretionary accruals quality and negatively impacts on innate accruals quality. Finally, size of board of directors negatively impacts discretionary accruals quality and positively influences on innate accruals quality.
\end{abstract}

C 2012 Growing Science Ltd. All rights reserved.

\section{Introduction}

During the past few years, there has been growing interest on proposing new methods and techniques to assess transparency of financial statement. Many people argue that the recent financial crisis in United States banking system was a result of violating rules and regulations. Therefore, many have attempted to find the relationship between corporate governance mechanisms and the quality of reported earnings in publicly traded companies. Jensen and Meckling (1976) are believed to be the first who introduced the idea of corporate governance. In their study, they studied the relationship between the owners and managers where each part try to maximize their benefits and since there is not a unique flow of information between these two groups we see conflict of interest among them. Corporate governance will help reduce any existing conflict and provide a fair flow of information between two parties (Gillan, 2006).

\footnotetext{
* Corresponding author. Tel: +09127520226

E-mail addresses: phdmnn@gmail.com (M. Nazari) 
Klapper and Love (2004) investigated corporate governance, investor protection, and performance in emerging markets. They used the relevant information on firm-level corporate governance (CG) rankings across 14 emerging markets and reported that there was a wide variation in firm-level governance and the average firm-level governance was lower in countries with weaker legal systems. They also detected the determinants of firm-level governance and reported that governance was correlated with the extent of the asymmetric information and contracting imperfections that firms face. Based on their results, better corporate governance was significantly associated with better operating performance and market valuation. They also provided some evidences, where firm-level corporate governance provisions are more important in countries with weak legal environments.

Bauer et al. (2008) investigated the level of disclosure ensured by corporate governance codes in force in European Union member states based on OECD rules and regulations. They performed a comparative study on different existing features of corporate governance in the literature by using econometric analysis based on different statistical tools such as descriptive analysis, mainly based on computing tools, and correlations to detect the relationship between their results and what others researchers achieved. The results of the performed analysis disclosed that their results were not consistent with prior research findings associated with disclosure as "primary theme" of corporate governance codes. By analyzing the results, they have reached to the same conclusion as other researchers did on the same topic. Finally, they reported that we could certify that the compliance of corporate governance codes with OECD principles was consistent with prior research results associated with disclosure considering codes' issuer type and countries' legal regime.

Ştefănescu (2011) performed an investigation to find the level of disclosure ensured by corporate governance codes in force in European Union member states. She reported that common law regime could likely ensure the biggest level of transparency through corporate governance needs. They also asserted that the compliance of corporate governance codes with OECD principles was consistent with prior research achievement associated with disclosure considering codes' issuer type and countries' legal regime. Ammann et al. (2011) studied the relationship between firm-level corporate governance and firm value based on a dataset from Governance Metrics International (GMI), which includes 6663 firm-year observations from 22 developed countries over the period of 2003-2007. Based on a set of 64 individual governance attributes they built two alternative additive corporate governance indices with equal weights. The corporate governance attributed to the governance attributes and one index derived from a principal component analysis and they reported a strong and positive relation between firm-level corporate governance and firm valuation. Besides, they studied the value associated with governance attributes, which document the companies' social behavior. Their findings were robust against alternative calculation procedures for the corporate governance indices and to alternative estimation techniques.

Black et al. (2012) first conducted a case study of Brazil, in which they studied Brazilian firms' governance practices at year-end 2004, constructed a corporate governance index, and demonstrated that the index for ownership structure, board procedure, and minority shareholder rights, predicts higher lagged Tobin's q. Nelson (2005) investigated the link between firm performance, CEO characteristics and changes in corporate governance practices based on unbalanced panel of 1721 over the period of 1980-1995. The paper provided the stylized facts about corporate governance practices and explained how governance practices had evolved over time. They reported no relationship between CEO age, tenure or compensation and governance changes. Fama and Jensen (1983) performed a deep investigation on separation of ownership and control and finally, Dechow and Dichev (2002) studied the quality of accruals and earnings by looking into the role of accruals estimation errors. Francis et al. (2005) investigated different parameters influencing accruals quality including total assets, loss reported in financial statement, life cycle of inventory and receivable accounts and operating revenue divided by total assets based on a linear regression analysis and discussed the findings. 
In this paper, we present an empirical study to find the relationship between discretionary accruals quality as well as innate accruals quality and portion of non-executive board of directors, concentration of ownership ratio and board size in Tehran Stock Exchange.

\section{The proposed study}

\subsection{Variables}

PROIND: Percentage of non-executive members to total number of executive member

CONC: Concentration of ownership ratio, the ratio determines portions of the people who own at least five percent of the shares

DAQ: $\quad$ Discretionary accruals quality

IAQ: $\quad$ Innate accruals quality

Board size: The number of people who take part in editorial board

$\Delta \mathrm{WC}_{\mathrm{t}} \quad$ The change in working capital in time $t$ compared with previous period $t-1$

$\mathrm{CFO}_{\mathrm{t}-1} \quad$ Cash flow in period $\mathrm{t}-1$

$\mathrm{CFO}_{\mathrm{t}} \quad$ Cash flow in period $\mathrm{t}$

$\mathrm{CFO}_{\mathrm{t}+1} \quad$ Cash flow in period $\mathrm{t}+1$

$\triangle \mathrm{Rev}_{\mathrm{t}} \quad$ Change in operating revenue for two consecutive period

$\mathrm{PPE}_{\mathrm{t}} \quad$ Fixed asset in period $\mathrm{t}$

AQ Accruals quality

SIZE $_{t} \quad$ Natural logarithm of total assets in period $t$

LOSS $_{t} \quad$ The number of years that firm reports loss in its statement

$\mathrm{OPCYC}_{t} \quad$ Natural logarithm of mean life cycle of inventory and receivable accounts

SDOR $_{t} \quad$ Standard deviation of operating revenue divided by total assets

The main hypothesis of this paper considers whether there is a relationship between concentration of ownership and board of director's characterization with discretionary accruals quality and Innate accruals quality. The proposed study of this paper considers the following six hypotheses,

1. The relationship between the ratio of non-executive members of board of directors and discretionary accruals quality,

2. The relationship between the ratio of non-executive members of board of directors and Innate accruals quality,

3. The relationship between the ratio of size of board of directors and Innate accruals quality,

4. The relationship between the ratio of size of board of directors and discretionary accruals quality,

5. The relationship between concentration of ownership and Innate accruals quality,

6. The relationship between concentration of ownership and discretionary accruals quality.

The proposed study of this paper gathers the necessary data from Tehran Stock Exchange based on some predefined rules and regulations. According to our regulation, all stocks must be tradable for the period of studies. They must have a unique fiscal year ending March and must not have changes their business model within the period of studies. The other requirement is that no financial firm including banks, insurance or holding company is permitted. Finally, the structure of board of directors must be available for study. Based on these criteria, the information of 118 firms have been qualified for the proposed study of this paper and using sampling technique, 42 companies have been gathered. Table 1 shows descriptive information on our survey. The study has adopted the study accomplished by Kent et al. (2010). 
Table 1

Descriptive information for 42 firms

\begin{tabular}{|c|c|c|c|c|c|c|c|c|c|c|c|}
\hline \multicolumn{2}{|c|}{ Var. } & $\Delta \mathrm{WC}_{\mathrm{t}}$ & $\mathrm{CFO}_{\mathrm{t}-1}$ & $\mathrm{CFO}_{\mathrm{t}}$ & $\mathrm{CFO}_{\mathrm{t}+1}$ & $\Delta \operatorname{Rev}_{\mathrm{t}}$ & $\mathrm{PPE}_{\mathrm{t}}$ & SIZE $_{t}$ & $\mathrm{LOSS}_{\mathrm{t}}$ & $\mathrm{OPCYC}_{\mathrm{t}}$ & $\mathrm{SDOR}_{\mathrm{t}}$ \\
\hline \multicolumn{2}{|c|}{ Mean } & 356.161 & 1226.729 & 3226.449 & 2612.636 & 1600.466 & 859.0678 & 34.5339 & 3.5 & 34.822 & 153284.1 \\
\hline \multicolumn{2}{|c|}{ Std. Dev. } & 41.61921 & 145.82 & 98.95449 & 39.36156 & 15.09866 & 5.07043 & 0.5294 & 0.10475 & 0.54808 & 9716.019 \\
\hline \multicolumn{2}{|c|}{ Median } & 3677 & 520.5 & 3445.5 & 2573.5 & 1595 & 865 & 34.5 & 4 & 35 & 147300.5 \\
\hline \multicolumn{2}{|c|}{ Mode } & 2975 & 180 & $2235.00^{\mathrm{a}}$ & 2136 & 1381 & $816.00^{\mathrm{a}}$ & 38 & 4 & 36.00 & 314.89 \\
\hline \multicolumn{2}{|c|}{ Std. Dev. } & 452.1003 & 1584.01 & 1075.247 & 427.576 & 164.0135 & 55.07892 & 5.75078 & 1.13792 & 5.95371 & $1.06 \mathrm{E}+05$ \\
\hline \multicolumn{2}{|c|}{ Variance } & 204394.7 & 2509088 & 1156156 & 182821.2 & 26900.42 & 3033.688 & 33.071 & 1.295 & 35.447 & $1.11 \mathrm{E}+10$ \\
\hline \multicolumn{2}{|c|}{ Skewness } & -0.224 & 2.378 & 0.441 & 0.253 & 0.041 & 0.805 & 0.069 & -0.62 & 0.202 & 0.152 \\
\hline \multicolumn{2}{|c|}{$\begin{array}{c}\text { Std. dev. } \\
\text { Skewnesss }\end{array}$} & 0.223 & 0.223 & 0.223 & 0.223 & 0.223 & 0.223 & 0.223 & 0.223 & 0.223 & 0.223 \\
\hline \multirow{3}{*}{$\begin{array}{l}\text { Percent } \\
\text { quartile }\end{array}$} & 25 & 3056.5 & 323 & 2249.5 & 2214 & 1443 & 813.75 & 31 & 3 & 30 & 58565.41 \\
\hline & 50 & 3677 & 520.5 & 3445.5 & 2573.5 & 1595 & 865 & 34.5 & 4 & 35 & 147300.5 \\
\hline & 75 & 3999 & 1602 & 4111.25 & 3024.25 & 1771.25 & 886.25 & 38 & 4 & 38 & 245987.2 \\
\hline
\end{tabular}

In order to perform regression analysis for the following two linear regression model we need to verify normality test.

$\Delta \mathrm{WC}_{\mathrm{t}}=\beta_{0}+\beta_{1} \mathrm{CFO}_{\mathrm{t}-1}+\beta_{2} \mathrm{CFO}_{\mathrm{t}}+\beta_{3} \mathrm{CFO}_{\mathrm{t}+1}+\beta_{4} \Delta \mathrm{Rev}_{\mathrm{t}}+\beta_{5} \mathrm{PPE}_{\mathrm{t}}+\mathrm{e}_{\mathrm{t}}$

$\mathrm{AQ}=\alpha+\beta_{1} \mathrm{SIZE}_{\mathrm{t}}+\beta_{2} \mathrm{LOSS}_{\mathrm{t}}+\beta_{3} \mathrm{OPCYC}_{\mathrm{t}}+\beta_{4} \mathrm{SDOR}_{\mathrm{t}}+\mathrm{e}_{\mathrm{t}}$

The first step in performing regression analysis is to make sure that dependent variable is normally distributed and to perform this, we perform Kolmogorov-Smirnov (KS) test and $\mathrm{KS}$ value for $\mathrm{WC}_{\mathrm{t}}$ is calculated as 0.401 . Fig. 1 shows distribution of residuals for regression analysis given in Eq. (1) as follows,

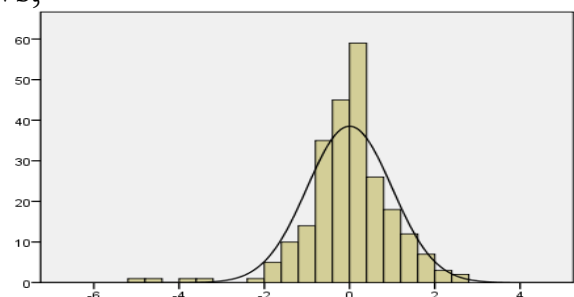

Fig. 1. Distribution of residuals for $\Delta \mathrm{WC}_{\mathrm{t}}$

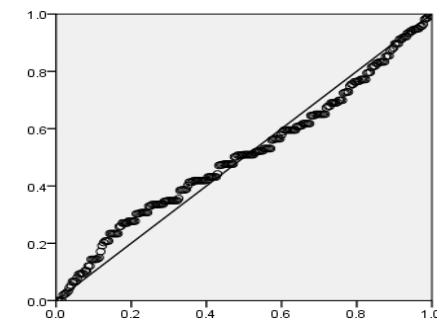

Fig. 2. Cumulative probability for dependent variable $\Delta \mathrm{WC}_{\mathrm{t}}$

Based on the results of KS and Fig. 1 and Fig. 2 we can conclude that data are normally distributed. The other test is to study the correlation among independent variables. Table 2 shows the results of Pearson correlation test for independent variables.

Table 2

The results of Pearson correlation test for Eq. (1)

\begin{tabular}{clcccccc}
\hline & & $\mathrm{WCT}$ & $\mathrm{CFO}_{\mathrm{t}-1}$ & $\mathrm{CFO}_{\mathrm{t}}$ & $\mathrm{CFO}_{\mathrm{t}+1}$ & $\mathrm{ReV}$ & $\mathrm{PPE}$ \\
\hline \multirow{2}{*}{$\mathrm{WCT}$} & Pearson test & 1 & $0.262^{* *}$ & $0.695^{* *}$ & $0.655^{* *}$ & $0.648^{* *}$ & $0.446^{* *}$ \\
& Level of significance & & 0.004 & 0.000 & 0.000 & 0.000 & 0.000 \\
\hline \multirow{2}{*}{$\mathrm{CFO}_{\mathrm{t}-1}$} & Pearson test & $0.262^{* *}$ & 1 & 0.078 & 0.057 & 0.125 & 0.152 \\
& Level of significance & 0.004 & & 0.400 & 0.536 & 0.178 & 0.100 \\
\hline \multirow{2}{*}{$\mathrm{CFO}_{\mathrm{t}}$} & Pearson test & $0.695^{* *}$ & 0.078 & 1 & $0.938^{* *}$ & $0.959^{* *}$ & $0.592^{* *}$ \\
& Level of significance & 0.000 & 0.400 & & 0.000 & 0.000 & 0.000 \\
\hline \multirow{2}{*}{$\mathrm{CFO}_{\mathrm{t}+1}$} & Pearson test & $0.655^{* *}$ & 0.057 & $0.938^{* *}$ & 1 & $0.936^{* *}$ & $0.657^{* *}$ \\
& Level of significance & 0.000 & 0.536 & 0.000 & & 0.000 & 0.000 \\
\hline \multirow{2}{*}{$\mathrm{Rev}$} & Pearson test & $0.648^{* *}$ & 0.125 & $0.959^{* *}$ & $0.936^{* *}$ & 1 & $0.646^{* *}$ \\
& Level of significance & 0.000 & 0.178 & 0.000 & 0.000 & & 0.000 \\
\hline \multirow{2}{*}{$\mathrm{PPE}$} & Pearson test & $0.446^{* *}$ & 0.152 & $0.592^{* *}$ & $0.657^{* *}$ & $0.646^{* *}$ & 1 \\
& Level of significance & 0.000 & 0.100 & 0.000 & 0.000 & 0.000 & \\
\hline
\end{tabular}

**Results is valid when the level of significance is set to 0.01 
As we can observe from the results of Table 2, there are some strong correlations among independent variables and we need to use stepwise regression analysis. Similarly, we perform KolmogorovSmirnov (KS) test and $\mathrm{KS}$ value for $\mathrm{WC}_{\mathrm{t}}$ is calculated as 1.406. Fig. 3 shows distribution of residuals for regression analysis given in Eq. (2) as follows,

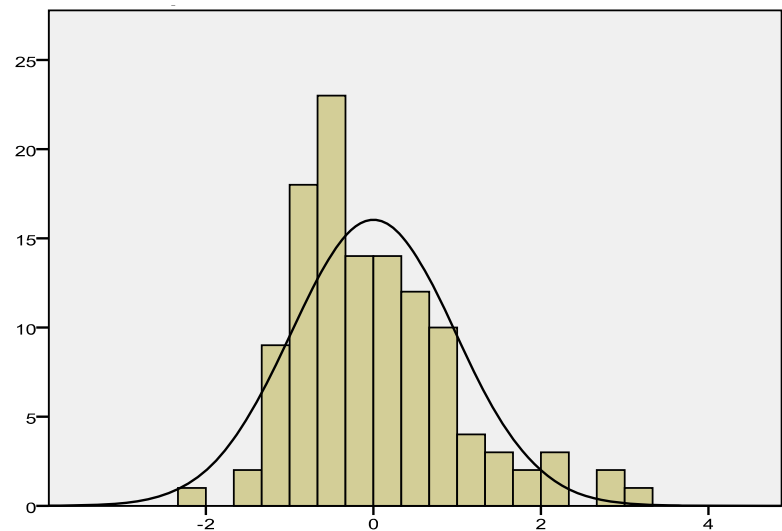

Fig. 3. Distribution of residuals in AQ equation

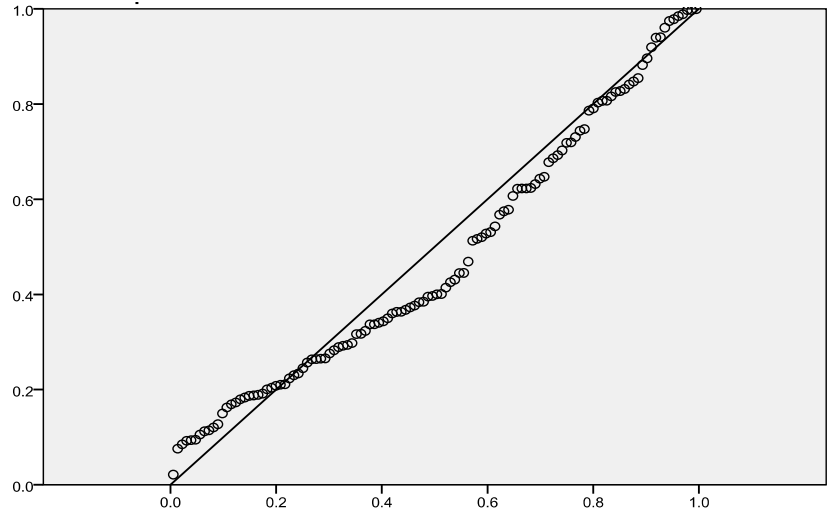

Fig. 4. Cumulative probability for dependent variable AQ

Based on the results of KS and Fig. 3 and Fig. 4 we can conclude that data are normally distributed. The other test is to study the correlation among independent variables. Table 3 shows the results of Pearson correlation test for independent variables.

Table 3

The results of Pearson correlation test for Eq. (2)

\begin{tabular}{clccccc}
\hline & & Standard predicted error & SIZE $_{t}$ & LOSS $_{t}$ & OPCYC $_{t}$ & SDOR $_{t}$ \\
\hline \multirow{2}{*}{ AQ } & Pearson test & 1 & $0.418^{* *}$ & 0.016 & 0.067 & $0.438^{* *}$ \\
& Level of significance & & 0.000 & $0.864^{* *}$ & 0.470 & 0.000 \\
\hline \multirow{2}{*}{ SIZEt } & Pearson test & $0.418^{* *}$ & 1 & -0.105 & $0.250^{* *}$ & $0.752^{* *}$ \\
& Level of significance & 0.000 & & 0.257 & 0.006 & 0.000 \\
\hline \multirow{2}{*}{ LOSSt } & Pearson test & -0.016 & -0.105 & 1 & -0.045 & -0.125 \\
& Level of significance & 0.864 & 0.257 & & 0.630 & 0.177 \\
\hline \multirow{2}{*}{ OPCYC } & Pearson test & 0.067 & $0.250^{* *}$ & -0.045 & 1 & $0.303^{* *}$ \\
t & Level of significance & 0.470 & 0.006 & 0.630 & 0.001 \\
\hline \multirow{2}{*}{ SDORt } & Pearson test & $-0.438^{* *}$ & $0.752^{* *}$ & -0.125 & $0.303^{* *}$ & 1 \\
& Level of significance & 0.000 & 0.000 & 0.177 & 0.001 & \\
\hline
\end{tabular}

**Results is valid when the level of significance is set to 0.01

Again, we see some strong correlation between some independent variables, which implies that we need to use stepwise regression analysis.

\section{The results}

In this section, we first present details of our regression analysis for the Eq. (1) and Eq. (2).

\subsection{The first model}

The implementation of stepwise linear regression for the first model is summarized in Table 4 as follows, 


\section{Table 4}

The results of regression analysis when the dependent variable is WCT $\left(\mathrm{R}^{2}=0.80\right)$

\begin{tabular}{|c|c|c|c|c|c|c|}
\hline & \multirow{2}{*}{ Model } & \multicolumn{2}{|c|}{ Non-standard coefficients } & \multirow{2}{*}{$\frac{\text { Standard coefficients }}{\text { Beta }}$} & \multirow{2}{*}{$\mathrm{t}$} & \multirow{2}{*}{ Error } \\
\hline & & $\mathrm{B}$ & Std. dev & & & \\
\hline \multirow{6}{*}{1} & Intercept & 3542.003 & 773.434 & & 4.580 & 0.000 \\
\hline & $\mathrm{CFO}_{\mathrm{t}-1}$ & 0.066 & 0.019 & 0.231 & 3.490 & 0.001 \\
\hline & $\mathrm{CFO}_{\mathrm{t}}$ & 0.406 & 0.107 & 0.966 & 3.798 & 0.000 \\
\hline & $\mathrm{CFO}_{\mathrm{t}+1}$ & 0.174 & 0.221 & 0.164 & 2.786 & 0.004 \\
\hline & Rev & $1.357-$ & 0.700 & $0.492-$ & $1.938-$ & 0.000 \\
\hline & PPE & 0.403 & 0.726 & 0.049 & 2.556 & 0.005 \\
\hline
\end{tabular}

As we can observe from the results of Table 4, all t-student values are valid and the regression covers $91 \%$ of the results. The results of regression analysis is summarized as follows,

$$
\Delta \mathrm{C}_{\mathrm{t}}=3542.003+0.066 \mathrm{CFO}_{\mathrm{t}-1}+0.406 \mathrm{CFO}_{\mathrm{t}}+0.174 \mathrm{CFO}_{\mathrm{t}+1}-1.357 \Delta \mathrm{Rev}_{\mathrm{t}}+0.403 \mathrm{PPE}_{\mathrm{t}}+773.434 \mathrm{e}_{\mathrm{t}}
$$

Table 5 shows the results of ANOVA test.

\section{Table 5}

The results of ANOVA test for Eq. (1)

\begin{tabular}{ccccccc}
\hline & Model & Sum of Least squares & df & Mean & F & Level of significance \\
\hline \multirow{2}{*}{1} & RSS & $1.296 \mathrm{E} 7$ & 5 & 2591266.8 & 26.485 & 0.000 \\
& ESS & $1.096 \mathrm{E} 7$ & 36 & 97837.93 & & \\
\hline
\end{tabular}

As we can observe from the results of ANOVA test, the null hypothesis can be rejected when the level of significance is one percent and we can conclude that the first linear regression is valid.

\subsection{The second model}

The implementation of stepwise linear regression for the second model is summarized in Table 6 as follows,

Table 6

The results of regression analysis when the dependent variable is AQ $\left(\mathrm{R}^{2}=0.81\right)$

\begin{tabular}{ccccccc}
\hline \multirow{2}{*}{ Model } & \multicolumn{2}{c}{ Non-standard coefficients } & Standard coefficients & \multirow{2}{*}{ t } & \multirow{2}{*}{ Error } \\
\cline { 3 - 6 } & B & Std. dev & Beta & & 5.214 & 0.000 \\
\hline \multirow{4}{*}{2} & Intercept & 89.063 & 17.082 & 0.207 & -1.701 & 0.092 \\
& SIZEt & 0.752 & 0.442 & 0.72 & 2.515 & 0.010 \\
& LOSSt & 1.319 & 1.481 & 0.216 & 2.561 & 0.012 \\
& OPCYCt & 0.757 & 0.295 & 0.364 & -2.936 & 0.004 \\
\hline
\end{tabular}

As we can observe from the results of, except two cases, the other coefficients maintain valid tstudent values. Eq. (4) shows details of our findings,

$$
\mathrm{AQ}=89.063+0.752 \mathrm{SIZE}_{\mathrm{t}}+1.319 \mathrm{LOSS}_{\mathrm{t}}+0.757 \mathrm{OPCYC}_{\mathrm{t}}+7.202 \mathrm{SDOR}_{\mathrm{t}}+17.082 \mathrm{e}_{\mathrm{t}}
$$

Similarly, we have performed ANOVA test for the second model and Table 7 shows details of our findings. As we can observe from the results of ANOVA test, the null hypothesis can be rejected when the level of significance is one percent and we can conclude that the first linear regression is valid. 
Table 7

ANOVA test results for the second model

\begin{tabular}{|c|c|c|c|c|c|c|}
\hline Model & & SUM of Squares & $\mathrm{df}$ & Mean & $\mathrm{F}$ & Error \\
\hline \multirow{3}{*}{2} & RSS & 14451.136 & 5 & 2890.227 & 8.836 & 0.000 \\
\hline & ESS & 36635.387 & 36 & 327.102 & & \\
\hline & TSS & 51086.523 & 41 & & & \\
\hline
\end{tabular}

\subsection{The impact of PROIND, CONC and BOARD SIZE on DAQ and IAQ}

In this section, we perform structural equation modeling (SEM) to determine the effects of three PROIND, CONC and BOARD SIZE on two variables of DAQ and IAQ using LISREL software packages. Fig. 5 shows details of our results for the proposed SEM model,

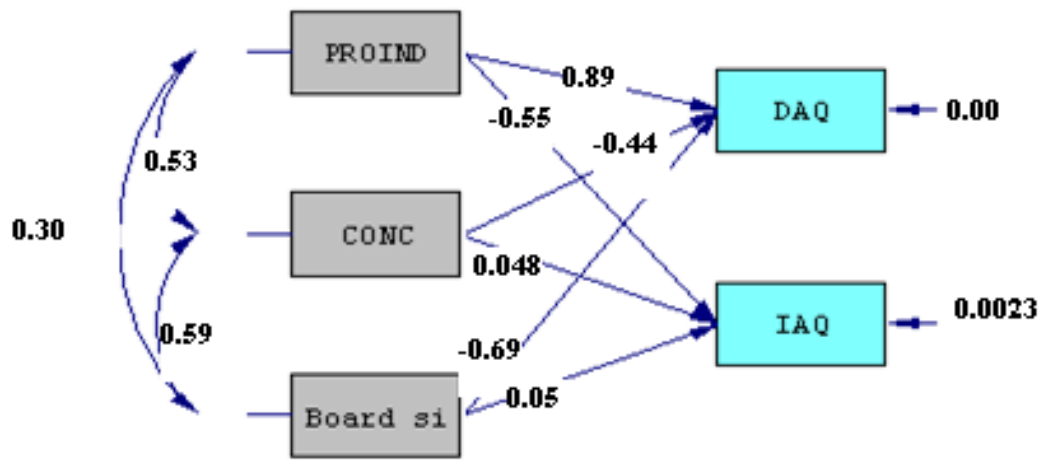

Fig. 5. The results of SEM model

Based on the results, we can derive the following results,

$\mathrm{DAQ}=0.89 * \mathrm{PROIND}-0.44 * \mathrm{CONC}-0.69 *$ Board SIZE $\quad$ Error var. $=0.0012, \mathrm{R}^{2}=0.95$

$\mathrm{IAQ}=-0.55 \mathrm{PROIND}+0.048 * \mathrm{CONC}+0.05 *$ Board size $\quad$ Error var. $=0.002, \mathrm{R}^{2}=0.93$

In our proposed model, the ratio of Chi-Square on degree of freedom is $1.6<3$, NFI is equal to 0.97 , NNFI is 0.93 , CFI is equal to 0.92, GFI and AGFI are also equal to 0.91 and 0.90 , respectively. The results confirm the findings of SEM model. Table 8 shows the summary of our results.

\section{Table 8}

The summary of our results for six hypotheses

\begin{tabular}{clll}
\hline Hypothesis & Path & P Value & Results \\
\hline$H_{1}^{\prime}$ & Proind $\rightarrow$ DAQ & $<0.001$ & Accept \\
$H_{2}^{\prime}$ & Proind $\rightarrow$ IAQ & $<0.001$ & Accept \\
$H_{3}^{\prime}$ & Conc $\rightarrow$ DAQ & $<0.001$ & Accept \\
$H_{4}^{\prime}$ & Conc $\rightarrow$ IAQ & $<0.001$ & Accept \\
$H_{5}^{\prime}$ & Board Size $\rightarrow$ DAQ & $<0.001$ & Accept \\
$H_{6}$ & Board Size $\rightarrow$ IAQ & $<0.001$ & Accept \\
\hline
\end{tabular}

As we can observe from Table 8, all eight hypotheses have been confirmed and we can conclude that an increase on non-executive members positively influences on discretionary accruals quality and negatively influences innate accruals quality. Concentration of ownership ratio positively influences on discretionary accruals quality and negatively impacts on innate accruals quality. Finally, size of 
board of directors negatively impacts discretionary accruals quality and positively influences on innate accruals quality.

\section{Conclusion}

In this paper, we have presented an empirical study to find the relationship between discretionary accruals quality as well as innate accruals quality and portion of non-executive board of directors, concentration of ownership ratio and board size in Tehran Stock Exchange. The survey selected 118 qualified stocks from this exchange and using a random technique selected 42 companies. The study used two linear regression techniques to estimate the first part of the information and then using structural equation modeling examined six hypotheses. Based on the results of this survey we can conclude that an increase on non-executive members positively influences on discretionary accruals quality and negatively influences innate accruals quality. Concentration of ownership ratio positively influences on discretionary accruals quality and negatively impacts on innate accruals quality. Finally, size of board of directors negatively impacts discretionary accruals quality and positively influences on innate accruals quality.

\section{Acknowledgment}

The authors would like to thank the anonymous referees for constructive comments on earlier version of this paper.

\section{References}

Ammann, M., Oesch, D., \& Schmid, M. M. (2011). Corporate governance and firm value: International evidence. Journal of Empirical Finance, 18(1), 36-55.

Bauer, R., Frijns, B., Otten, R., \& Tourani-Rad, A. (2008). The impact of corporate governance on corporate performance: Evidence from Japan. Pacific-Basin Finance Journal, 16(3), 236-251.

Black, B.S., de Carvalho, A.G., \& Gorga, É (2012). What matters and for which firms for corporate governance in emerging markets? Evidence from Brazil (and other BRIK countries). Journal of Corporate Finance, 18(4), 934-952.

Cohen, J., Krishnamoorthy, G., \& Wright, A. (2002). Corporate governance and the audit process. Contemporary Accounting Research 19, 573-592.

Dechow, P., \& Dichev, I. (2002). The quality of accruals and earnings: the role of accruals estimation errors. The Accounting Review, Supplement, 77, 35-59.

Fama, E. F., \& Jensen, M. (1983). Separation of ownership and control. Journal of Law and Economics, 26, 301-325.

Francis, J., LaFond, R., Olsson, P.M., \& Schipper, K. (2005). The market pricing of accruals quality. Journal of Accounting and Economics 39, 295-327.

Gillan, S.L. (2006). Recent developments in corporate governance: An overview. Journal of Corporate Finance, 12(3), 381-402.

Kent, P., Routledge, J., \& Stewart, J. (2010). Innate and discretionary accruals quality and corporate governance. Accounting and Finance, 50, 171-195.

Klapper, L.F., \& Love, I. (2004). Corporate governance, investor protection, and performance in emerging markets. Journal of Corporate Finance, 10(5), 703-728.

Jensen, M.C., \& Meckling, W.H. (1976). Theory of the firm: managerial behavior, agency costs and ownership structure. Journal of Financial Economics, 3(40), 305-360.

Nelson, J. (2005). Corporate governance practices, CEO characteristics and firm performance. Journal of Corporate Finance, 11(1-2). 197-228.

Ştefănescu, C.A. (2011). Disclosure and transparency in corporate governance codes - comparative analysis with prior literature findings. Procedia - Social and Behavioral Sciences, 24, 1302-1310. 